\title{
Field Evaluation and Use of a Non Commercial Peptide Enzyme Immunoassay for Human Immunodeficiency Virus Serotyping in Abidjan (Ivory Coast)
}

\author{
Inwoley $\mathrm{A}^{1,2^{*}}$, Affi-Aboli $\mathrm{R}^{1}$, Kabran $\mathrm{M}^{1,2}$, Ouassa $\mathrm{T}^{1,2}$, Koui $\mathrm{S}^{1}$, Seri $\mathrm{B}^{1}$, Rouet $\mathrm{F}^{2}$ and Barin $\mathrm{F}^{3}$ \\ ${ }^{1}$ Université Félix Houphouët Boigny, Abidjan, Ivory Coast \\ ${ }^{2}$ Centre for Diagnostic and Research for AIDS and Other Infectious Diseases. CHU Treichville, Abidjan, Ivory Coast \\ ${ }^{3}$ Université Francois-Rabelais, Inserm U966 and National Reference Center for HIV CHU Bretonneau, Tours, France \\ ${ }^{*}$ Corresponding author: Inwoley A, Université Félix Houphouët Boigny, Faculty of Pharmacy and Biology \\ 01 BP V34 Abidjan, Côte d'Ivoire, Fax: (+225) 212492 06, Tel: +225 21258459, E-mail: andre.inwoley@ \\ gmail.com
}

Citation: Inwoley A, Affi-Aboli R, Kabran M, Ouassa T, Koui S, et al. (2017) Field Evaluation and Use of a Non Commercial Peptide Enzyme Immunoassay for Human Immunodeficiency Virus Serotyping in Abidjan (Ivory Coast). J Immunol Infect Dis 4(1): 104

Received Date: January 17, 2017 Accepted Date: June 14, 2017 Published Date: June 16, 2017

\begin{abstract}
In West Africa, where Human Immunodeficiency Viruses 1 and 2 (HIV-1 and HIV-2) co-circulate, serological assays allowing the reliable serotyping of HIV infection are needed. This study evaluated the performance and described the experience in using a noncommercial peptide-based enzyme immunoassay (PBEIA) in a context of resource-limited setting.

The PBEIA uses peptides representative of the immunodominant regions of the transmembrane glycoprotein and the surface glycoprotein (V3 loop) of both HIV-1 (gp41 and V3.1) and HIV-2 (gp36 and V3.2). The evaluation of this assay was carried out using: 510 serum samples including 200 from HIV-negative individuals and 310 from HIV-positive individuals (130 HIV-1,105 HIV-2 and 75 HIV with dual seroreactivity) based on results obtained and 145 other samples positive for HIV-2. Murex HIV-1.2. ${ }^{\mathrm{TM}}$, Vironostika HIV Uni-Form II plus $\mathrm{O}^{\mathrm{TM}}$ and western blot tests were used as reference gold standard assays.

The sensitivity of gp41, gp36, V3.1 and V3.2 was 100\% (95\% confidence intervals [CI]: 100-100\%), 96.6\% (95\% CI: 94.5-97.9\%), 96.9\% (95\% CI: 95.4-98.4\%), and 60\% (95\% CI: 50.6-69.4\%), respectively. The specificity was 100\% for gp41, V3.1 and V3.2 (95\% CI: $100-$ $100 \%)$ and $97.7 \%$ (95\% CI: 94.4-99.9\%) for gp36. The discriminatory power of the PBEIA was very good with a Kappa value equal to 0.94. Operationally, PBEIA was convenient and presented a very low production cost, when compared to immunoblot testing. PBEIA was routinely used to analyze 15,734 samples from 2006 to 2013 and led to 198 (1.2\%) false negative results. Among the 759 samples which tested HIV-1+2 at dilution 1/100, only 334 (44\%) were confirmed HIV-1+2 at dilution 1/500, while $388(51.1 \%)$ and 37 (4.9\%) were reclassified as HIV-1 and HIV-2 mono-infections, respectively.

In conclusion, the excellent performance of PBEIA associated with its low cost confirmed that this assay can be used routinely by reference laboratories. This technique is also useful to reclassify all samples that are identified as HIV dually reactive with discriminatory rapid tests in peripheral laboratories.
\end{abstract}

Keywords: HIV; ELISA; serotyping; Ivory Coast

\section{Introduction}

HIV infection has become a global epidemic and a major public health problem worldwide. In 2015, among a total of 36.7 million [34.0-39.8] people living with HIV (PLHIV), 6.5 million [5.3-7.8] were in Western and Central Africa [1]. In West Africa, Ivory Coast displayed the highest prevalence rate which was $3.2 \%$ among subjects aged $15-49$ [2].

The fight against this pandemic needs simultaneous use of effective preventive action and wider access to treatment. However, in the absence of vaccine, fighting activities focus firstly on prevention through awareness of infection status and secondly on a better therapeutic management of infected persons. Given its importance in struggling against AIDS, biological diagnosis of HIV infection is importance and is based on the detection of antibodies in adults and children over 18 months. The "conventional" strategy associates antibody screening by one or more enzyme-linked immunosorbent assays (ELISA), and a confirmation of positive results with Western blot. This strategy is not always feasible in developing countries for many reasons. Indeed, this strategy 
requires appropriate laboratory equipment, qualified staff, and is characterized by a high cost. Thus, the World Health Organization (WHO) recommends to use simpler and cheaper alternative strategies such as rapid diagnostic tests (RDTs) for countries with limited resources [3]. There is a proliferation of commercial HIV screening tools, but according to the WHO, the genetic diversity of HIV requires the evaluation of any screening test prior to use in a given area [4]. In Ivory Coast, the predominant subtype of HIV-1 is the recombinant form CRF02_AG [5,6], but HIV-2 also circulates as in other countries of West Africa [7]. Therefore, screening strategies must also include a discriminating test in order to determine the HIV serotype in patients, mainly because of the natural resistance of HIV-2 to non-nucleoside inhibitors of reverse transcriptase $[8,9]$.

RDTs able to discriminate between HIV-1- or HIV-2- seroreactivity have been developed. Although several studies have described the good performance of tests and algorithms used in West Africa for HIV diagnosis the limited performances of discriminating rapid tests were noted [10-13]. A large-scale implementation of more efficient commercial assays is challenging in countries with limited resources.

During the past two decades, non-commercial ELISA's assays have been developed for HIV serotyping dedicated to epidemiological studies conducted in developed countries. For instance, Barin, et al.. used a non-commercial ELISA based on peptides representative of immunodominant regions of the HIV glycoproteins (peptide-based enzyme immunoassay, [PBEIA]) to achieve the monitoring of HIV strains circulating in France [14-16].

The objectives of this study were to transfer and evaluate the performance of this tool in Ivory Coast and to describe its routine use during 8 years in our laboratory.

\section{Materials and Methods}

\section{Assessment Panels}

PBEIA evaluation was conducted from June 2004 to November 2005 on two different sera panels from the biobank of the Centre for Diagnostic and Research for AIDS and Other Infectious Diseases (CeDReS) located at the teaching hospital of Treichville in Abidjan, Ivory Coast.

Sera of Panel 1 were collected from pregnant women attending in six urban community based antenatal clinics in the city of Abidjan during the ANRS 1201/1202 DITRAME PLUS project from March 2001 to April 2003. This was an open cohort conducted in Abidjan whose objective was to evaluate the efficacy of antiretroviral short regimens (AZT + NVP and AZT +3 TC $+\mathrm{NVP})$ in preventing mother to child transmission of HIV (PMTCT) [17]. This panel consisted of 510 samples including 200 negative and 310 positive (130 HIV-1, 105 HIV-2 and 75 HIV-1+2 dual reactivity), according to WB results.

Panel 2 was obtained from patients who were enrolled in three HIV care centers of Abidjan: department of pneumology/teaching hospital of Treichville, Abidjan Integrated Center for Bio-Clinical Research (CIRBA) and Center for Care, Research and Training (CePReF). This panel contained 145 samples positive for HIV-2, according to ELISA and WB results. Samples were collected during a study dedicated to an evaluation rapid test for the health ministry from January to march 2007.

\section{Ethical considerations}

The ANRS 1201/1202 DITRAME PLUS study (for panel 1) and rapid test evaluation (for panel 2) were approved by the Ivorian ministry of health ethical committee and all participants gave their consent for HIV testing.

\section{Description of the PBEIA}

PBEIA is an indirect enzyme-linked immunosorbent assay adapted from that described by Barin and colleagues [15]. PBEIA used for HIV-1 synthetic peptides of the immunodominant region of gp41 (consensus sequence of all clades and consensus of clade D respectively, RVLAVERYLKDQQLLGIWGCSGKLICTTAV and RILAVESTLKDQQLLGIWGCSGRHICTTAV) and the V3 loop (named V3.1). For HIV-2, PBEIA used synthetic peptides of the immunodominant region of gp 36 (RVTAIEKYLKDQAQLNSWGCAFRQVGHTTV) and the V3 loop (V3.2, respectively). These peptides were produced by PolyPeptide Laboratories (France) and used as antigens of the solid phase to coat FALCON flexible plates (BD Biosciences. Belgium). The coating was made in our laboratory with these antigens at the concentration of $1 \mu \mathrm{g} / \mathrm{ml}(\mathrm{gp} 41 \mathrm{and} \mathrm{gp} 36) \mathrm{or} 2.5 \mu \mathrm{g} /$ $\mathrm{ml}$ (V3.1 and V3.2) with overnight incubation at $37^{\circ} \mathrm{C}$. Then, after 3 washes with $150 \mu$ l of wash buffer (phosphate buffered saline with $0.5 \%$ Tween 20 ), wells are saturated with $200 \mu \mathrm{l}$ of blocking buffer (phosphate buffered saline containing $2 \%$ fetal calf serum) (Sigma-Aldrich. USA) at $37^{\circ} \mathrm{C}$ for 45 minutes, followed by three washes as above. After drying, plates are ready for use or can be wrapped in aluminum foil and stored at $-20^{\circ} \mathrm{C}$ for 6 weeks.

For serotyping, a 96-well plate is brought back to room temperature before use. Each sample and controls to be tested are diluted to $1 / 100$ in a buffer (phosphate buffered saline containing $10 \%$ fetal calf serum and $0.005 \%$ tween 20 ). Only the samples retested were diluted to $1 / 500$. One hundred microliters of each diluted sample are added to 4 wells of the plate allowing incubation with the 4 peptides (gp41, gp36, V3.1 and V3.2). In each plate, 3 negative controls, one HIV-1 positive control and one HIV-2 positive control are included. Thirty minutes after incubation at $18{ }^{\circ} \mathrm{C}$, wells are subjected to 5 washes with $150 \mu \mathrm{l}$ wash buffer each. 
Thereafter, $100 \mu$ l of 1/5000 dilution of conjugate: $\left(\mathrm{F}^{\prime}(\mathrm{ab}) 2\right)$ anti-human immunoglobulin G goat antibody coupled to peroxidase (Clinisciences. Strasbourg) are distributed in each well of the plate and incubated for 30 minutes at $18^{\circ} \mathrm{C}$. After 5 washes, revelation is done by adding $100 \mu \mathrm{l}$ of Ortho-phenylenediamine hydrochloride Di-fast as substrate (Sigma-Aldrich. USA). After incubation in the dark for 15 minutes at $18{ }^{\circ} \mathrm{C}$, reaction is stopped by adding $50 \mu \mathrm{l}$ of $2 \mathrm{~N}$ sulfuric acid per well. The optical density (OD) is measured at $490 \mathrm{~nm}$ with a reference filter at $630 \mathrm{~nm}$ within 30 minutes.

\section{Reference tests}

For panel 1, samples were screened by performing the Murex HIV-1.2.O ${ }^{\mathrm{TM}}$ (Abbott. Dartford. United Kingdom) and Vironostika HIV Uni-form II plus O ${ }^{\mathrm{TM}}$ (Organon Teknika, Boxtel, Netherlands). Then, HIV serotyping was done with the Pepti-LAV-1/2 ${ }^{\mathrm{TM}}$ (BioRad Diagnostics, Marne-La Coquette, France). Any sample which gave a discordant result between the PBEIA and Peptilav1/2 ${ }^{\mathrm{TM}}$ was analyzed further by Western Blot assays: New Lav blot I and New Lav blot II ${ }^{\mathrm{TM}}$ (BioRad Diagnostics, Marne-laCoquette, France).

For panel 2, samples were screened with Vironostika HIV Uni-form II plus $\mathrm{O}^{\mathrm{TM}}$ assay and serotyped with New lav blot I and New lav blot II ${ }^{\mathrm{TM}}$. In all cases, Western blot tests were interpreted according to the WHO criteria $[4,18]$.

\section{Experience of use}

After its evaluation, PBEIA was used routinely at CeDReS between 2006 and 2013 for serotyping through the following algorithm. All samples were tested with Vironostika HIV Uni-Form II Ag/Ab ${ }^{\mathrm{TM}}$ for screening. Positive samples were serotyped with the PBEIA. For negative results, samples were retested by both tests. In case of HIV dual reactivity by PBEIA, samples were retested at dilution $1 / 500$.

\section{Statistical analysis}

Results obtained with panel 1 were used to calculate the negativity threshold value (NTV) and the positive threshold value (PTV) using the following formulas: (i) NTV $=$ (average negOD) +3 (standard deviation of negOD). (ii) PTV $=($ average posOD) +3 (standard deviation of posOD).

For screening, sensitivity and specificity were calculated by comparing the PBEIA to non-discriminatory tests i.e. Murex HIV1.2. $\mathrm{O}^{\mathrm{TM}}$ (Abbott. Dartford. United Kingdom) or Vironostika HIV Uni-form II plus O ${ }^{\mathrm{TM}}$. For serotyping, sensitivity of each peptide was calculated for its ability to identify the right serotype. Similarly, specificity of each peptide was calculated for its ability to identify the correct serotype. Kappa concordance value was also calculated [19].

\section{Results}

\section{Determination of threshold values}

Figure 1a shows distribution of ODs obtained with PBEIA for 200 negative samples. NTV obtained for gp41, V3.1, V3.2 and gp36 peptides were respectively: $1.15 ; 1.26 ; 0.95$ and 0.85 . Given these values were close to 1 , the NTV was set to 1 for all peptides.
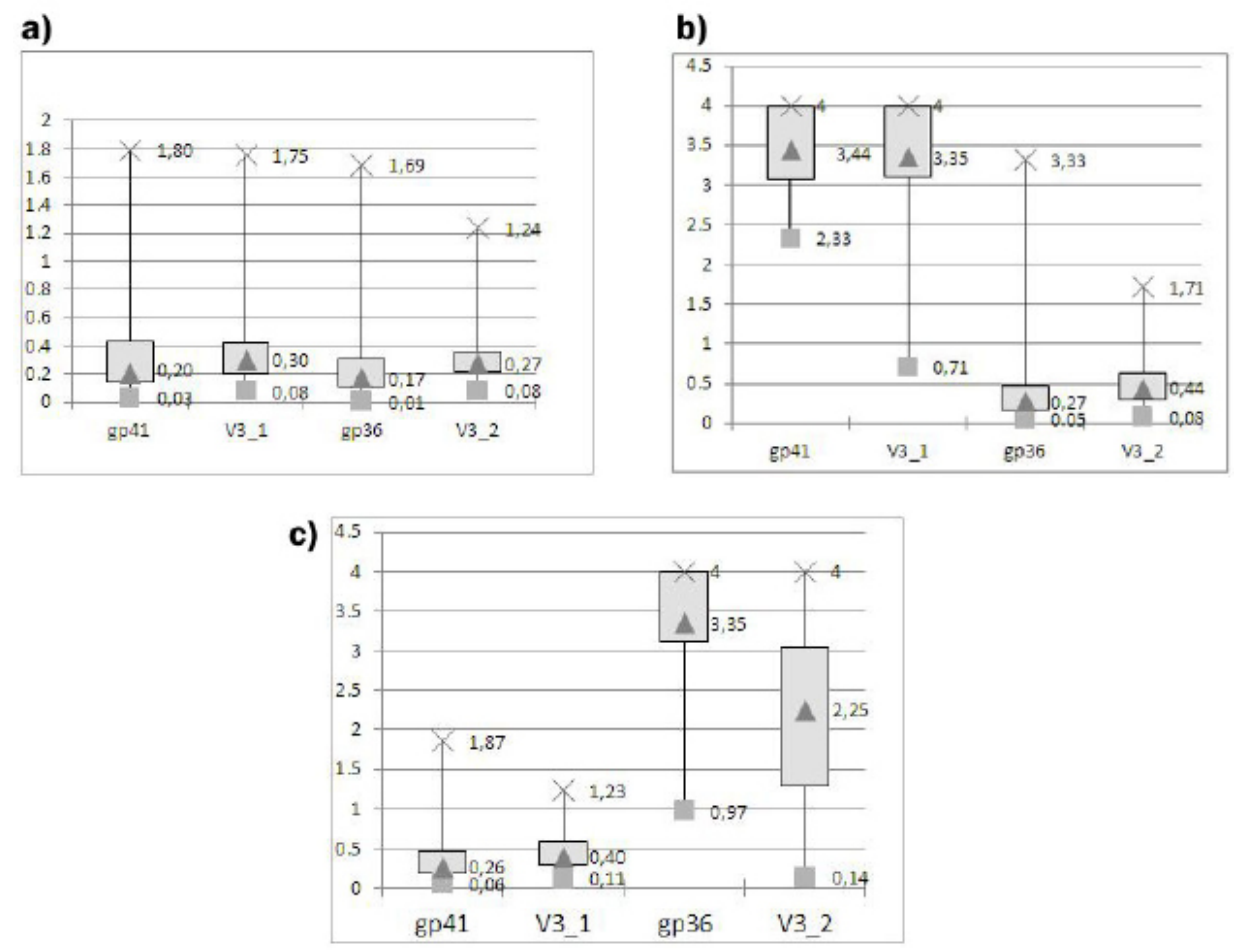

Figure 1: Distribution of optical densities (y-axis) of peptides (x-axis) of HIV samples tested negative (a) HIV-1 positive (b) and HIV-2 positive (c) $\times$ :maximum, $\mathbf{A}$ : median, $\square$ :minimum 
Thus, all samples showing an OD of less than 1 were considered negative by PBEIA. Negative threshold value at dilution $1 / 500$ was set at 0.5 by applying the same principle. We also determined the PTV by analyzing ODs of HIV serotype 1 samples on the one hand and those of HIV serotype 2 on the other hand. PTV was set to 2 at dilution 1/100 (Figures $1 \mathrm{~b}$ and 1c). PTV was set to 1 for dilution $1 / 500$.

Detection performance of each peptide used for HIV-1 and HIV-2 serotypes at NTV and PTV thresholds is shown in Table 1. On panel 1, according to the PTV, HIV-1 sensitivity of gp41 and V3.1 peptides was 100\% (95\% CI: 100-100\%) and 96.9\% (95\% CI: 95.4-98.4\%), respectively. For HIV-2, sensitivity of gp36 and V3.2 peptides was 96.2\% (95\% CI: 94.5-97.9\%) and 60\% (95\% CI: 50.6-69.4\%), respectively. Regarding specificity, at threshold value 2, specificity of gp41, V3.1 and V3.2 peptides was 100\% (95\% CI: 100-100\%) whereas specificity of gp36 peptide was 97.7\% (95\% CI: $94.4-99.9 \%)$. Thus, among four samples which were negative at threshold 2 with gp36, three ones with OD between 1 and 2 were positive with this peptide at 1/500 dilution because OD was more than 1. At threshold value 1, cross-reactivity was obtained with all peptides with a higher frequency for HIV-2 peptides. Any sample, for which a cross-reaction was suspected (OD between 1 and 2) with at least one of the peptides, was retested at dilution 1/500. At this dilution, samples that gave an OD lower than 0.5 (NTV of this dilution) were declared negative with this peptide.

\begin{tabular}{|c|c|c|c|c|c|c|c|c|c|}
\hline \multirow{2}{*}{} & \multicolumn{5}{|c|}{ Panel 1 } & \multicolumn{3}{c|}{ Panel 2 } \\
\cline { 2 - 11 } & \multicolumn{3}{|c|}{ HIV-1 (N=130) } & \multicolumn{3}{c|}{ HIV-2 (N=105) } & \multicolumn{3}{c|}{ HIV-2 (N=145) } \\
\cline { 2 - 11 } & $\mathrm{OD} \geq 2$ & $1<\mathrm{OD}<2$ & $\mathrm{OD} \leq 1$ & $\mathrm{OD} \geq 2$ & $1<\mathrm{OD}<2$ & $\mathrm{OD} \leq 1$ & $\mathrm{OD} \geq 2$ & $1<\mathrm{OD}<2$ & $\mathrm{OD} \leq 1$ \\
\hline Gp 41 & 130 & 0 & 0 & 0 & 1 & 104 & 0 & 11 & 134 \\
\hline V 3.1 & 126 & 2 & 2 & 0 & 2 & 103 & & & \\
\hline Gp 36 & 3 & 11 & 116 & 101 & 3 & 1 & 136 & 9 & 0 \\
\hline V 3.2 & 0 & 6 & 124 & 54 & 23 & 28 & & & \\
\hline
\end{tabular}

All these results allowed us to define stringent criteria for the interpretation of the PBEIA: (i) consider only transmembrane peptides gp41 (HIV-1) and gp36 (HIV-2); (ii) samples giving an OD greater than 2 are considered positive for each peptide; (iii) samples giving an OD between 1 and 2 for a peptide, as well as positive samples for both peptides at 1/100 dilution should be retested on the same plate at both dilutions 1/100 and 1/500; (iv) samples tested at dilution 1/500 must be considered as positive if the OD is greater than 1.

\section{Performance of the PBEIA}

Regarding the screening performance of the PBEIA, we obtained one false negative out of 310 positive samples, leading to a sensitivity of $99.7 \%$ (95\% CI: 99.2-100\%) and a specificity of 100\% (95\% CI: 100-100\%). This false negative sample was from an HIV-2 infected individual. The positive and negative predictive values were 100\% (95\% CI: 100-100\%) and 99.5\% (95\% CI: 98.9$100 \%)$, respectively.

The discriminatory power of the PBEIA, in comparison with the Pepti-LAV $1 / 2^{\mathrm{TM}}$ assay, was high, with a Kappa value equal to 0.94 (Table 2).

\begin{tabular}{|c|c|c|c|c|c|}
\hline \multirow{2}{*}{\multicolumn{2}{|c|}{$\mathrm{K}=\mathbf{0 . 9 4}$}} & \multicolumn{4}{|c|}{ Pepti-LAV $1 / 2^{\mathrm{TM}}$} \\
\hline & & HIV-1 & HIV-2 & HIV-1+HIV-2 & Total \\
\hline \multirow{4}{*}{ PBEIA } & HIV-1 & 129 & 0 & 6 & 135 \\
\hline & HIV-2 & 0 & 104 & 4 & 108 \\
\hline & HIV-1+HIV-2 & 1 & 0 & 65 & 66 \\
\hline & Total & 130 & 104 & 75 & 309 \\
\hline
\end{tabular}

\begin{tabular}{|c|c|c|c|}
\hline Number & PBEIA & Pepti-LAV $\mathbf{1} \mathbf{2}^{\text {TM }}$ & New LAV Blot $^{\text {TM }}$ I/ II \\
\hline 11539 & HIV-2 & HIV-1+2 & HIV-2 \\
\hline 11648 & HIV-2 & HIV-1+2 & HIV-2 \\
\hline 11886 & HIV-2 & HIV-1+2 & HIV-2 \\
\hline 20274 & HIV-1 & HIV-1+2 & HIV-1 \\
\hline 20773 & HIV-2 & HIV-1+2 & HIV-2 \\
\hline 20994 & HIV-1 & HIV-1+2 & HIV-1 \\
\hline 30346 & HIV-1 & HIV-1+2 & HIV-1+2 \\
\hline 31753 & HIV-1 & HIV-1+2 & HIV-1 \\
\hline 32496 & HIV-1+2 & HIV-1 & HIV-1+2 \\
\hline 32940 & HIV-1 & HIV-1+2 & HIV-1 \\
\hline 70176 & HIV-1 & HIV-1+2 & \\
\hline
\end{tabular}


Serological profiles of the eleven samples which gave discordant results (3.6\% discrepancy rate) are presented in Table 3. Of these, concordant results between PBEIA and Western blot assay were found for eight samples (72.7\% concordance rate).

Results obtained on panel 2 are shown in Table 1. Using a threshold of 2, the sensitivity of gp36 peptide was $93.8 \%$ (95\% CI 89.9-97.7\%). The 11 samples detected by gp41 which had OD values ranging between 1 and 2 at dilution 1/100 were retested at dilution1/500. At this dilution, all of them gave an OD less than 0.5 and therefore were declared negative with this peptide. However, the 9 samples detected by gp36 with an OD between 1 and 2 at dilution 1/100 and retested at dilution 1/500, gave an OD greater than 1 and then declared positive. In total, PBEIA showed 100\% concordant results with Western Blot on panel 2.

Operationally, the PBEIA was convenient and had a lower cost price, when compared to Pepti-LAV-1/2 ${ }^{\mathrm{TM}}$ (Table 4). However, its implementation can only be performed in laboratories with an adapted technical platform with at least an ELISA system.

\begin{tabular}{|c|c|c|}
\hline KIT & PBEIA & Pepti-LAV $1 / 2^{\mathrm{TM}}$ \\
\hline Sample volume & $10 \mu \mathrm{l}$ & $30 \mu \mathrm{l}$ \\
\hline Dilution & $1 / 100$ & $1 / 100$ \\
\hline Working Temperature & $18^{\circ} \mathrm{C}$ & Room Temperature \\
\hline Duration of the Test & 1h $30 \mathrm{mn}$ & 1h $45 \mathrm{mn}$ \\
\hline Reading Mode & Spectrophotometer $490 / 630 \mathrm{~nm}$ & Visual \\
\hline Storing Temperature & $-20^{\circ} \mathrm{C}$ & +2 à $8{ }^{\circ} \mathrm{C}$ \\
\hline Cost of Production & 1 USD & 25 USD \\
\hline
\end{tabular}

\section{User experience of the PBEIA}

During the eight years of use, 15,734 samples were tested in first intention (at dilution 1/100) with 15,462 samples HIV-positive. 272 (1.7\%) were tested negative and 760 tested positive for both HIV-1 and HIV-2 (HIV dual). After retesting the 272 samples negative by PBEIA, 74 were finally found positive including 50 with an OD lower than 2 for both peptides. It is noteworthy that when the OD ratio between the two peptides was greater than 5, the serotype is determined by the peptide having the highest OD. After retesting at dilution 1/500, the 760 samples which were dual positive at dilution 1/100, we obtained the following results: 388 HIV-1, 37 HIV-2 and 335 dual positives. Table 5 show distribution of ODs obtained respectively with gp 41 and gp 36 at the two dilutions, according to the final serotype found. For the 388 samples which tested HIV-1 positive with gp 41 peptide, only $7.7 \%$ (30/388) displayed an OD less than 1 at dilution 1/500. Similarly for the 37 samples which tested positive for HIV-2, 8\% (3/37) presented an OD less than 1 at dilution 1/500 with gp 36 peptide. Overall, 1.3\% negative results were obtained and the distribution of serotypes was $92.9 \%$. 3.7\% and $2.1 \%$ for HIV-1, HIV-2 and HIV-dual reactive respectively.

\begin{tabular}{|c|c|c|c|c|c|c|c|c|c|}
\hline \multirow{2}{*}{ Serotypes } & \multirow{2}{*}{$\begin{array}{c}\text { Dilution } \\
1 / 100\end{array}$} & \multicolumn{4}{|c|}{ gp41 Dilution 1/500 } & \multicolumn{4}{|c|}{ gp 36 Dilution 1/500 } \\
\hline & & $\mathrm{OD} \leq 0.5$ & $0.5<\mathrm{OD}<1$ & $1<\mathrm{OD}<2$ & $\mathrm{OD} \geq 2$ & $\mathrm{OD} \leq 0.5$ & $0.5<\mathrm{OD}<1$ & $1<\mathrm{OD}<2$ & $\mathrm{OD} \geq 2$ \\
\hline \multirow{4}{*}{ HIV1 } & $\mathrm{OD} \leq 0.5$ & 0 & 0 & 0 & 0 & 6 & 0 & 0 & 0 \\
\hline & $0.5<\mathrm{OD}<1$ & 0 & 0 & 4 & 0 & 20 & 3 & 0 & 0 \\
\hline & $1<\mathrm{OD}<2$ & 1 & 15 & 34 & 5 & 252 & 49 & 0 & 0 \\
\hline & $\mathrm{OD} \geq 2$ & 0 & 14 & 74 & 241 & 36 & 22 & 0 & 0 \\
\hline \multirow{3}{*}{ HIV2 } & $0.5<\mathrm{OD}<1$ & 1 & 1 & 0 & 0 & 0 & 0 & 0 & 0 \\
\hline & $1<\mathrm{OD}<2$ & 22 & 8 & 0 & 0 & 0 & 2 & 5 & 1 \\
\hline & $\mathrm{OD} \geq 2$ & 4 & 1 & 0 & 0 & 0 & 1 & 13 & 15 \\
\hline \multirow{4}{*}{ HIV1+2 } & $\mathrm{OD} \leq 0.5$ & 0 & 0 & 0 & 0 & 0 & 0 & 1 & 0 \\
\hline & $0.5<\mathrm{OD}<1$ & 0 & 3 & 1 & 0 & 1 & 4 & 1 & 1 \\
\hline & $1<\mathrm{OD}<2$ & 1 & 16 & 37 & 8 & 3 & 38 & 61 & 10 \\
\hline & $\mathrm{OD} \geq 2$ & 0 & 4 & 48 & 216 & 1 & 13 & 109 & 91 \\
\hline
\end{tabular}

Table 5: Comparison of optical densities for peptides gp41 and gp36 at dilutions 1/100 and 1/500 for retested HIV dual samples $(\mathrm{n}=759)$

\section{Discussion}

In countries with limited resources, monitoring and diagnosis of HIV infection are major Public Health challenges [20]. Immunoassays including ELISA and RDTs are the most common and widespread diagnostic methods [21,22]. More efficient tests for serotyping such as Pepti-LAV ${ }^{\mathrm{TM}}$ and Western blot are very expensive for countries with limited resources [11,23]. Moreover, the production of some commercial discriminating ELISA formats by developed countries was stopped for lack of profitability. In this context, technical performance of a non-commercial ELISA (PBEIA) and its use for eight years were assessed. This study was conducted in West Africa with a local panel gathering all the conditions related to the variability of HIV strains in a given territory, 
especially in Africa. Negative samples showed optical densities greater than those previously obtained with negative sera in French population $[14,15]$. In fact, OD median value for each of the peptides was around 0.3 while Barin described ODs lower than 0.1 for negative controls $[14,15]$. This difference could be explained by: (i) the presence of other types of antibodies in the sera of subjects living in Africa, (ii) the living environment that promotes infection and therefore a greater stress for the immune system. We also recommend to include in each run of PBEIA positive and negative controls in order to validate the test: mean of negative control $<0.5$ and positive control of each peptide $>2$.

The performance analysis of each peptide revealed that synthetic peptides including gp41 and gp36 sequences were excellent candidates for the diagnosis of HIV infection. Barin et al has been reported that the discriminating power of the PBEIA could be slightly improved by combining immunodominant epitope of both gp41 and V3 [15]. Nevertheless, we obtained a low sensitivity of V3.1 peptide of HIV-1 and the two peptides of HIV-2 (gp36 and V3.2).In our study, V3 loop had no interest in determining the serotype of positive samples which finally took into account only the results of transmembrane peptides gp 41 and gp36. Recently, Tiwari et al. developed a new antigenic cocktail including the 32 amino-acids heterovalent and oligomeric peptides "V3-I" in combination with gp41, gp36 and rp24. This increased the sensitivity and the specificity of an indirect ELISA assay developed for detecting anti HIV-1 and HIV-2 antibodies, thereby eliminating non-specific cross-reactivity. Moreover, a cross-reaction was observed with gp36 for two HIV-1 positive samples [24,25]. These cross-reactions are mitigated when the samples were diluted at $1 / 500$ instead of $1 / 100$. The low sensitivity (96.2 \%) of gp36 was comparable to those reported with commercial discriminating ELISA kits whose production was discontinued [23,26,27]. This difficulty in detecting HIV-2 could be due to low HIV-2 viral loads, a characteristic of the HIV-2 natural infection, or could be due to the lack of detection of some subtypes of HIV-2. Indeed, HIV-2 variants of subtypes B are common in Côte d'Ivoire and we could have missed amplification our molecular technique [28,29]. The reduced sensitivity of the PBEIA may also be caused by improper selection of antigen and/or reduction of HIV-2 antibody levels in patients [30-32]. Marcellino increased to $100 \%$ the sensitivity an HIV-2 ELISA by using two new recombinant proteins, rgp36 and rpc2-C3 from HIV-2 primary reference isolate ALI [33-35]. These data were consistent with previous studies showing that gp36 recombinant proteins derived from HIV-2 strains of several laboratories are highly immunogenic [35-37]. It appears that routine use of PBEIA in our context, could disregard these V3 peptides. Thus, a ready-to-use ELISA plate could allow testing 48 samples instead of 24, and therefore reducing the unit price of the test.

Performance analysis of gp41 and gp36 peptides confirms the good sensitivity and specificity observed with the PBEIA. These results were similar to those obtained by Simon F and colleagues who found $98 \%$ specificity for an indirect ELISA developed from synthetic peptides gp41/gp36 and V3 of 4 lentivirus lines [38]. Although the sensitivity of PBEIA does not reach 100\%, our data show that its good specificity makes it useful in a serial algorithm as second test for serotyping. The very good agreement between PBEIA and Pepti-LAV-1/2 ${ }^{\mathrm{TM}}$ shows that it is a good alternative to commercial assay. Many dual-reactive samples by western blot were not confirmed by PBEIA. These results were consistent with previous studies including that of Tchounga, et al. who reported poor discrimination of dually infected samples in cohort of HIV-2 infected patients from 3 West African countries (Ivory Coast. Mali. Burkina Faso) $[11,12,39,40,41]$. The choice of serotyping techniques for HIV infection should take into account not only the technical performance but also the operational characteristics and the cost of the test. For a laboratory with ELISA system and qualified staff, the use of PBEIA is a good alternative. Indeed, PBEIA is suitable for large series of samples. In addition, PBEIA presents lower price cost (about 1 USD). While, Pepti-LAV $1 / 2^{\mathrm{TM}}$ and NEW LAV BLOT ${ }^{\mathrm{TM}}$ were more expensive with 25 USD and 100 USD per test. However, the routine use for nearly a decade (since 2006) of PBEIA at our lab CeDReS can raise some challenges: (i) Have enough flexibility in a results interpretation despite existence of positive and negative threshold values. (ii) Necessity to have another discriminant assay as an alternative for samples tested negative with PBEIA but positive with non-discriminatory assays. (iii) Necessity to retest at both dilutions (1/100 and 1/500) all samples giving an HIV-dual result at dilution 1/100 in order to reduce cross-reactions.

\section{Conclusion}

The excellent performance associate with low price cost of PBEIA reinforced our routine use of this discriminating assay. It may be used in reference laboratories to retest all samples dually reactive with discriminating rapid tests in peripheral laboratories. It would reduce the rate of HIV dual and render the management of antiretroviral treatments more accurate.

\section{References}

1. UNAIDS (2016) Global AIDS Response Progress Reporting (GARPR) 2016.

2. UNAIDS (2015) Estimations VIH et SIDA 2015.

3. UNAIDS (1997) Revised recommendations for the selection and use of HIV antibody tests. Wkly Epidemiol Rec Health Sect Secr Leag Nations 72: 81-8.

4. Centers for Disease Control and Prevention (U.S) World Health Organization, Regional Office for Africa (2006) Guidelines for Appropriate Evaluations of HIV Testing Technologies in Africa.

5. Nkengasong JN, Luo CC, Abouya L, Pieniazek D, Maurice C, et al. (2000) Distribution of HIV-1 subtypes among HIV-seropositive patients in the interior of Côte d'Ivoire. J Acquir Immune Defic Syndr 23: 430-36.

6. Toni TA, Masquelier B, Bonard D, Faure M, Huët C, et al. (2002) Primary HIV-1 drug resistance in Abidjan (Côte d'Ivoire): a genotypic and phenotypic study. AIDS 16: 488-91. 
7. Ekouevi DK. Balestre E. Coffie PA. Minta D. Messou E. et al. (2013) Characteristics of HIV-2 and HIV-1/HIV-2 Dually Seropositive Adults in West Africa Presenting for Care and Antiretroviral Therapy: The IeDEA-West Africa HIV-2 Cohort Study. PLoS One 8: e66135.

8. Ren J, Bird LE, Chamberlain PP, Stewart-Jones GB, Stuart DI, et al. (2002) Structure of HIV-2 reverse transcriptase at 2.35-A resolution and the mechanism of resistance to non-nucleoside inhibitors. Proc Natl Acad Sci U S A 99: 14410-15.

9. Witvrouw M, Pannecouque C, Switzer WM, Folks TM, De Clercq E, et al. (2004) Susceptibility of HIV-2. SIV and SHIV to various anti-HIV-1 compounds: implications for treatment and post exposure prophylaxis. Antivir Ther 9: 57-65.

10. Koblavi-Dème S, Maurice C, Yavo D, Sibailly TS, N'guessan K, et al. (2001) Sensitivity and Specificity of Human Immunodeficiency Virus Rapid Serologic Assays and Testing Algorithms in an Antenatal Clinic in Abidjan. Ivory Coast. J Clin Microbiol 39: 1808-12.

11. Rouet F, Ekouevi DK, Inwoley A, Chaix ML, Burgard M,et al. (2004) Field Evaluation of a Rapid Human Immunodeficiency Virus (HIV) Serial Serologic Testing Algorithm for Diagnosis and Differentiation of HIV Type 1 (HIV-1). HIV-2. and Dual HIV-1-HIV-2 Infections in West African Pregnant Women. J Clin Microbiol 42: 4147-53

12. Tchounga BK, Inwoley A, Coffie PA, Minta D, Messou E, et al. (2014) Re-testing and misclassification of HIV-2 and HIV-1\&2 dually reactive patients among the HIV-2 cohort of The West African Database to evaluate AIDS collaboration. J Int AIDS Soc 17: 19064

13. Inwoley A, Ouassa T, Sevede D, Kabran M, Djety GV, et al. (2016) Evaluation of Rapid Tests and Identification of Algorithms for the screening and the serotyping of HIV Infection in West Africa. J Immunol Tech Infect Dis 5: 2.

14. Baillou A, Janvier B, Leonard G, Denis F, Goudeau A, et al. (1991) Fine serotyping of human immunodeficiency virus serotype 1 (HIV1) and HIV2 infections by using synthetic oligopeptides representing an immunodominant domain of HIV1 and HIV2/simian immunodeficiency virus. J Clin Microbiol 29: 1387-91.

15. Barin F, Plantier J-C, Brand D, Brunet S, Moreau A, et al. (2006) Human immunodeficiency virus serotyping on dried serum spots as a screening tool for the surveillance of the AIDS epidemic. J Med Virol 78: S13-18.

16. Semaille C, Barin F, Cazein F, Pillonel J, Brand D, et al. (2007) Monitoring the dynamics of the HIV epidemic using assays for recent infection and serotyping among new HIV diagnoses : experience after 2 years in France. J infect Dis $196: 377-83$.

17. Dabis F, Bequet L, Ekouevi DK, Viho I, Rouet F, et al. (2005) Field efficacy of zidovudine, lamivudine and single-dose nevirapine to prevent peripartum HIV transmission. AIDS 19: 309-18.

18. Essex M, Essex M (2002) AIDS in Africa. Springer Science \& Business Media.

19. Landis JR, Koch GG (1977) An application of hierarchical kappa-type statistics in the assessment of majority agreement among multiple observers. Biometrics 33: $363-74$.

20. Ribeiro-Rodrigues R, Ferreira da Silva Pinto Neto L, Cunha CB, Cabral VP, Dietze R (2003) Performance Characteristics of a Rapid New Immunochromatographic Test for Detection of Antibodies to Human Immunodeficiency Virus. Clin Diagn Lab Immunol 10: 303-7.

21. Aghokeng AF, Ewane L, Awazi B, Nanfack A, Delaporte E, et al. (2004) Evaluation of four simple/rapid assays and two fourth-generation ELISAs for the identification of HIV infection on a serum panel representing the HIV-1 group M genetic diversity in Cameroon. J Acquir Immune Defic Syndr 37: 1632-40.

22. Delaney KP, Branson BM, Uniyal A, Phillips S, Candal D, et al. (2011) Evaluation of the Performance Characteristics of 6 Rapid HIV Antibody Tests. Clin Infect Dis 52: 257-63.

23. Nkengasong JN, Maurice C, Koblavi S, Kalou M, Yavo D, et al. (1999) Evaluation of HIV serial and parallel serologic testing algorithms in Abidjan. Côte d'Ivoire AIDS Lond Engl 13:109-17.

24. Barin F, Meyer L, Lancar R, Deveau C, Gharib M, et al. (2005) Development and Validation of an Immunoassay for Identification of Recent Human Immunodeficiency Virus Type 1 Infections and Its Use on Dried Serum Spots. J Clin Microbiol 43: 4441-7.

25. Tiwari RP, Jain A, Khan Z, Kumar P, Bhrigu V, et al. (2013) Designing of novel antigenic peptide cocktail for the detection of antibodies to HIV-1/2 by ELISA. J Immunol Methods 387: 157-66.

26. Azevedo-Pereira JM, Lourenço MH, Barin F, Cisterna R, Denis F, et al. (1994) Multicenter evaluation of a fully automated screening test. VIDAS HIV $1+2$. for antibodies to human immunodeficiency virus types 1 and 2. J Clin Microbiol 32: 2559-63.

27. Centers for Disease Control (CDC) (1990) Surveillance for HIV-2 infection in blood donors--United States. 1987-1989. Morb Mortal Wkly Rep 39: 829-31.

28. McDougal JS, Pilcher CD, Parekh BS, Gershy-Damet G, Branson BM, et al. (2005) Surveillance for HIV-1 incidence using tests for recent infection in resourceconstrained countries. AIDS 19: S25-30.

29. Pieniazek D, Ellenberger D, Janini LM, Ramos AC, Nkengasong J, et al. (1999) Predominance of human immunodeficiency virus type 2 subtype B in Abidjan. Ivory Coast. AIDS Res Hum Retroviruses 15: 603-8.

30. Damond F, Apetrei C, Robertson DL, Souquière S, Leprêtre A, et al. (2001) Variability of human immunodeficiency virus type 2 (hiv-2) infecting patients living in france. Virology 280: 19-30.

31. Ishikawa K, Fransen K, Ariyoshi K, Nkengasong JN, Janssens W, et al. (1998) Improved detection of HIV-2 proviral DNA in dually seroreactive individuals by PCR. AIDS Lond. Engl. 12: 1419-25.

32. Lizeng Q, Nilsson C, Sourial S, Andersson S, Larsen O, et al. (2004) Potent Neutralizing Serum Immunoglobulin A (IgA) in Human Immunodeficiency Virus Type 2-Exposed IgG-Seronegative Individuals. J Virol 78: 7016-22.

33. Thorstensson R, Andersson S, Lindbäck S, Dias F, Mhalu F, et al. (1998) Evaluation of 14 commercial HIV-1/HIV-2 antibody assays using serum panels of different geographical origin and clinical stage including a unique seroconversion panel. J Virol Methods 70: 139-51.

34. Marcelino JM, Barroso H, Gonçalves F, Silva SM, Novo C, et al. (2006) Use of a New Dual-Antigen Enzyme-Linked Immunosorbent Assay To Detect and Characterize the Human Antibody Response to the Human Immunodeficiency Virus Type 2 Envelope gp 125 and gp36 Glycoproteins. J Clin Microbiol 44: 607-11.

35. Taveira NC, Bex F, Burny A, Robertson D, Ferreira MO, et al. (1994) Molecular characterization of the env gene from a non-syncytium-inducing HIV-2 isolate (HIV-2ALI). AIDS Res Hum Retroviruses 10: 223-4.

36. Huang ML, Essex M, Lee TH (1991) Localization of immunogenic domains in the human immunodeficiency virus type 2 envelope. J Virol 65: 5073-79.

37. Schulz TF, Oberhuber W, Hofbauer JM, Hengster P, Larcher C, et al. (1989) Recombinant peptides derived from the env-gene of HIV-2 in the serodiagnosis of HIV-2 infections. AIDS Lond. Engl 3:165-72.

38. Zuber M, Samuel KP, Lautenberger JA, Kanki PJ, Papas TS (1990) Bacterially produced HIV-2 env polypeptides specific for distinguishing HIV-2 from HIV-1 infections. AIDS Res Hum Retroviruses 6: 525-34. 
39. Simon F, Souquière S, Damond F, Kfutwah A, Makuwa M, et al. (2001) Synthetic Peptide Strategy for the Detection of and Discrimination among Highly Divergent Primate Lentiviruses. AIDS Res Hum Retroviruses 17: 937-52.

40. Peeters M, Gershy-Damet GM, Fransen K, Koffi K, Coulibaly M, et al. (1992) Virological and polymerase chain reaction studies of HIV-1/HIV-2 dual infection in Côte d'Ivoire. Lancet 340: 339-40.

41. Peeters M, Fransen K, Gershy-Damet G-M, Willems B, Koffi K, et al. (1994) Effect of methodology on detection of HIV-1/HIV-2 dual infections in Côte d'Ivoire. J Virol Methods 48: 23-30.

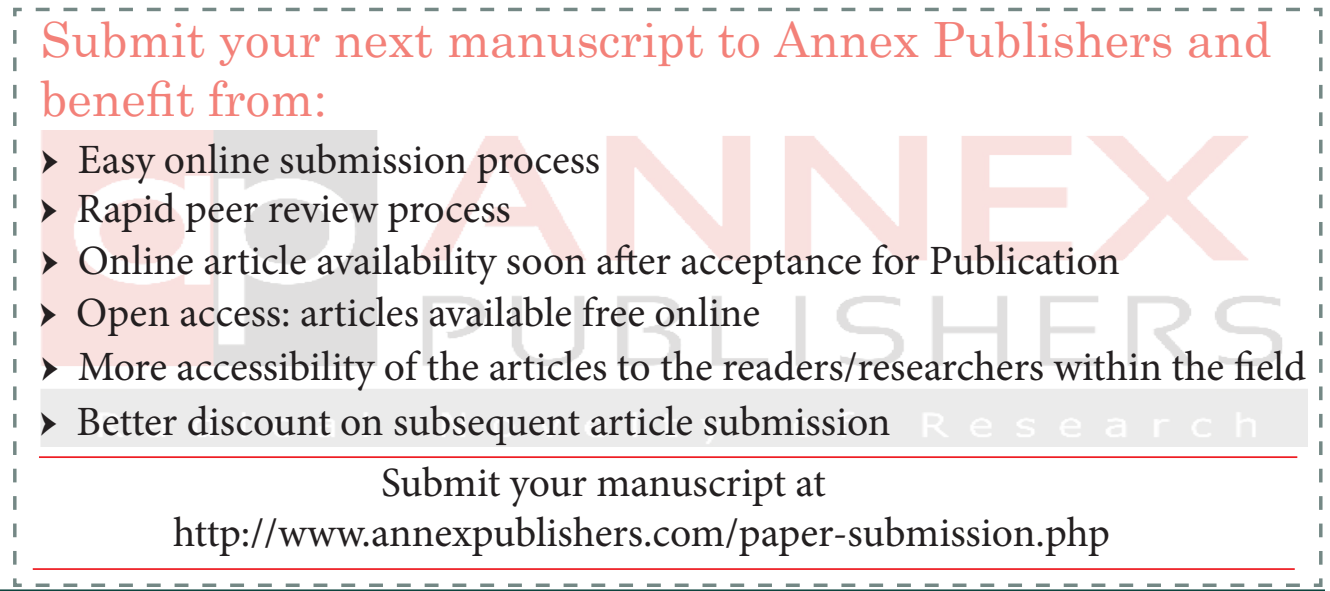

